\title{
THE INFLUENCE OF ADVERSITY QUOTIENT, NEED FOR ACHIEVEMENT, AND ENTREPRENEURIAL ATTITUDE ON ENTREPRENEURIAL INTENTION
}

\author{
Dina Fitriya Maharani, Aniek Indrawati, \& Thusy Tiara Saraswati \\ Universitas Negeri Malang
}

\begin{abstract}
This study aims to determine the effect of adversity quotient and need for achievement on entrepreneurial intention through entrepreneurial attitude. This study uses a quantitative approach. The population in this study amounted to 155 people with a sample of 112 people. Sampling uses probability sampling with proportional random sampling. Data collection was carried out by using a questionnaire and documentation. To analyze the data, the researcher used descriptive statistical analysis, classic assumption test, path analysis and hypothesis testing using $\mathrm{t}$ test and multiple tests. The analysis shows that: (1) adversity quotient influences entrepreneurial attitude, (2) need for achievement influences entrepreneurial attitude, (3) adversity quotient influences entrepreneurial intention, (4) need for achievement influences entrepreneurial intention. (5) Entrepreneurial attitude influences entrepreneurial intention, (6) entrepreneurial attitude is able to mediate the effect of adversity quotient on entrepreneurial intention, (7) entrepreneurial attitude is able to mediate the influence of need for achievement on entrepreneurial intention.
\end{abstract}

Keywords: adversity quotient, need for achievement, entrepreneurial attitude, entrepreneurial intention

\section{INTRODUCTION}

The poverty rate in East Java Province in the first quarter of 2019 was 179,900 people with a decrease of 0.48 percentage points. This is due to the Village Fund granting of Rp. 27.3 Trillion since 2015. Various community empowerment programs in East Java including the Village Fund program have been successful in reducing poverty in urban and rural areas. Although the East Java Provincial Government's efforts in fighting poverty have had results, it is indeed not yet optimal. It is because the population in East Java is still above the national poverty rate- $0.96 \%$ in percentage. The percentage of poor people in East Java in March 2019 was $10.37 \%$ while the average percentage of

\footnotetext{
*Corresponding Author.

e-mail: dinafitriya21@gmail.com
}

the national poor in March 2019 was 9.41\% (BPS Data, 2019).

In 2014, the Government raised the price of Premium Petrol gasoline by 31\% and Diesel by $36 \%$ which resulted in an increase in prices of almost all needs. It shows the still weak family economic resilience in the Province of East Java. It happens especially among vulnerable poor households in East Java, so that when economic changes occur even though they are very small, they can become poor or may become very poor. Harniati (2007) states that, in their vulnerability, although the people still have the ability to consume above the poverty line, they still have great potential to fall into the poor households. For households like these, a social security system is needed. 
Dina Fitriya Maharani, Aniek Indrawati, \& Thusy Tiara Saraswati / The Influence of Adversity Quotient, Need for Achievement, and Entrepreneurial Attitude on Entrepreneurial Intention / JEE, Vol. 9, No. 1, March 2020, pp 9-16

The Provincial Government of East Java is committed to carrying out sustainable development that is centered on the people, especially in favor of the poor (pro poor growth) and gender mainstreaming. Based on the Regional Long-Term Development Plan (RPJPD), in accordance with the East Java Province's Development Vision, "East Java is More Prosperous, Fair, Independent, Competitive, and Moral," and its mission, "More Independent and Prosperous with the Commoners". As well as in an effort to grow basic capital development achievements, the government is committed to improving and expanding the Poverty Reduction Program which is realized through the Other Road Program towards Independent and Prosperous (Jalin Matra).

The problem of poverty as a whole is a concern of the Provincial Government of East Java, but in particular the government is now observing an increase in the population of women living below the poverty line as well as the growing and acute conditions of poverty that occur in households with female heads of households. The phenomenon that is often known as the feminization of poverty requires special efforts in the context of handling it. In order to deal with these problems, the Government of East Java Province has designed a program to deal with women's poverty, especially for households with a Female Household Head (Kepala Rumah Tangga Perempuan/KRTP) through the Poverty Alleviation Feminization Mitigation Matter Program (Program Feminasi Kemiskinan/PFK).

The PFK program is not only a short-term effort to provide assistance to KRTP, but also a sustainable program in order to anticipate the existence of poverty traps in KRTP. In 2019, the implementation of the PFK Jalin Matra program has a target with the number of KRW 8,275 in 415 villages in 219 sub-districts in 19 districts and 1 city. The recipients of the PFK Jalin Matra Program must develop an entrepreneurial spirit so that the program can run as it should to alleviate poverty in East Java.

Entrepreneurial intentions in general often occur because of intentional acts or programs such as the Jalin Matra program. Entrepreneurs are required to pursue opportunities, enter new markets and offer new products. Entrepreneurial intentions can be interpreted as the process of finding information that can be used to achieve the objectives of forming a business (Katz and Gartner, 1988). In general, the stronger the intention to exhibit this behavior, the better the performance in trying. Individuals have a strong intention to have a business when they feel the business has a great feasibility and they have a desire to carry out business activities (Kearney et al., 2008). Intention captures motivational factors that can affect a person's behavior.

Meanwhile, to be an entrepreneur, individuals must have an entrepreneurial attitude, an adversity quotient, and a need for achievement. Entrepreneurial attitude includes aspects that help individuals to take action-taking responsibility for self-study, career and life (European Commission, 2012; Mopangga, 2014). The definition of adversity quotient according to (Zaki et al., 2006) is an assessment that measures how a person's response in dealing with a problem to be empowered and makes it an opportunity. According to (Sénchez \& Sahuquillo, 2012), need for achievement is motivation based on emotions and goals related to achievement. The need for self-achievement has been linked to entrepreneurial behavior. This motivational factor is an indication of how hard they try and how much effort they have in planning and implementing the entrepreneurial behavior. 
Dina Fitriya Maharani, Aniek Indrawati, \& Thusy Tiara Saraswati / The Influence of Adversity Quotient, Need for Achievement, and Entrepreneurial Attitude on Entrepreneurial Intention / JEE, Vol. 9, No. 1, March 2020, pp 9-16

Nurmawati (2017) states the results of her research on the effectiveness of Jalin Matra on Poverty Vulnerability Mitigation (PK2) in Ngroto Village, Pujon Subdistrict, Malang Regency as follows: 1) the effectiveness of the PK2 Jalin Matra Program seen from the aspect of income running less effectively, 2) the effectiveness of the PK2 Jalin Matra Program seen from the aspect of production has been effective, 3) of the 477 target households registered in the category of near poor households, so far those who can obtain loans amount to 49 households (10.27\%) so that the implementation of the PFK Jalin Matra Program seen from the aspect of capital is not yet effective. For this reason, it is necessary to consider increasing its effectiveness.

Anonimous (2016) showed that the average impact of the implementation of the PK2 Jalin Matra program on increasing RTS income in the study sites (Malang, Madiun, Jember and Sumenep) showed satisfactory results (63\%). Achievement of the increase in income at the RTS is at most between Rp500,000-<Rp1,000,000 (54\%) and less than Rp500,000 (42\%) and only 4\% has reached $\mathrm{Rp} 1,000,000-<\mathrm{Rp2,000,000}$. Thus, most RTS are able to obtain additional income of less than Rp1,000,000 which, if divided on average by four members per household, per capita will only get an increase of less than Rp250,000 on average. Meanwhile, the East Java Province poverty line in 2017 is $\mathrm{Rp} 360,302$ per capita per month.

\section{METHOD}

This research uses a quantitative approach with descriptive and explanatory research types. The instrument used was a closed questionnaire that had been tested for its validity and reliabil- ity. The population in this study were recipients of the Jalin Matra program in Batu City. The Researcher distributed questionnaires using Google Form. The sample in this study amounted to 112 respondents with Slovin formula. The sampling technique in this study is probability sampling. The type used in this study is Proportional Random Sampling where the samples in this study were taken proportionally with random sampling to determine the sample. To find out how influence the adversity quotient (X1) and need for achievement (X2), through entrepreneurial attitude $(Z)$ on entrepreneurial intention (Y), this study uses Path Analysis and Sobel Test techniques to determine the mediation between intermediate variables.

\section{RESULTS}

Based on the results of the descriptive analysis of respondents, the age of most respondents was in the range of $50-59$ by $57.1 \%$, the last education of the most respondents was junior high school graduates by $60.7 \%$, and the type of business that was chosen the most was food business as much as $45.5 \%$.

Based on the results of descriptive analysis of each variable, the average total score of the adversity quotient variable was 4.9. Therefore, it can be concluded that the recipients' adversity quotient of the Jalin Matra program is good. The average total score for the need for achievement variable is 4.6. So, it can be concluded that the need for achievement in the Jalin Matra program is very good. The average total score for the entrepreneurial attitude variable is 4.07. Hence, it can be concluded that the entrepreneurial attitude in the Jalin Matra program is good. The average total score for the entrepreneurial intention variable is 4.25 . 
Dina Fitriya Maharani, Aniek Indrawati, \& Thusy Tiara Saraswati / The Influence of Adversity Quotient, Need for Achievement, and Entrepreneurial Attitude on Entrepreneurial Intention / JEE, Vol. 9, No. 1, March 2020, pp 9-16

Thus, it can be concluded that entrepreneurial intention in the Jalin Matra program is very good. With the results of the normality test as shown p-plot has follow the diagonal.

Path analysis in this study is used to determine the direct and indirect effects between the independent variable (X1) adversity quotient and (X2) need for achievement, intervening variable $(Z)$ entrepreneurial attitude, and the dependent variable $(\mathrm{Y})$ entrepreneurial intention. The path analysis coefficient consists of two regression equations as follows:

\section{Structure Equation I and II}

In the first equation analysis, the regression happens from variable $\mathrm{X} 1$ to variable $\mathrm{Z}$ and from variable $X 2$ to variable $Z$. In the second equation analysis, namely regression from variable $\mathrm{X} 1$ to variable $\mathrm{Y}$, from variable $\mathrm{X} 2$ to variable $\mathrm{Y}$ and from variable $\mathrm{Z}$ to variable $\mathrm{Y}$. The results of the analysis can be seen in Table 1 .

These results indicate that the regression in the first equation, $\mathrm{X} 1$ has a significant effect on $\mathrm{Z}$ and $\mathrm{X} 2$ has a significant effect on $\mathrm{Z}$. The first structural equation model is formulated as follows:

$$
\begin{aligned}
\mathrm{Z} & =\rho \mathrm{zX} 1 \mathrm{X} 1+\rho \mathrm{zX} 2 \mathrm{X} 2+\rho \mathrm{z} \varepsilon_{1} \\
& =0.613+0.165+0.856
\end{aligned}
$$

The effect of the path coefficient error can be calculated as follows:

$$
\rho z \varepsilon_{1}=\sqrt{1-\mathrm{R}^{2}}=\sqrt{1-(0.517)^{2}}=0.856
$$

These results indicate that the regression in the second equation namely, X1, X2 and Z has a significant effect on $\mathrm{Y}$. The second structural equation model is formulated as follows:

$$
\begin{aligned}
\mathrm{Y} & =\rho \mathrm{X} 1 \mathrm{X} 1+\rho \mathrm{XX} 2 \mathrm{X} 2+\rho \mathrm{yz} \mathrm{Z}+\rho \mathrm{y} \varepsilon_{2} \\
& =0.212+0.263+0.431+0.795
\end{aligned}
$$

The effect of the path coefficient error can be calculated as follows:

$$
\rho y \varepsilon_{2}=\sqrt{1-\mathrm{R}^{2}}=\sqrt{1-(0.607)^{2}}=0.795
$$

The influence of adversity quotient (X1) and need for achievement (X2) through entrepreneurial attitude $(Z)$ on entrepreneurial in-

\begin{tabular}{|c|c|c|c|c|c|c|c|}
\hline Blok I & $\begin{array}{c}\text { Path } \\
\text { Coefficient }\end{array}$ & $\mathrm{t}$ & Sig. & Blok II & $\begin{array}{c}\text { Path } \\
\text { Coefficient }\end{array}$ & $\mathrm{T}$ & Sig. \\
\hline $\begin{array}{l}\text { Adversity } \\
\text { Quotient }\end{array}$ & .613 & 7.855 & .000 & $\begin{array}{l}\text { Adversity } \\
\text { Quotient }\end{array}$ & .212 & 2.423 & .017 \\
\hline $\begin{array}{l}\text { Need for } \\
\text { Achievement }\end{array}$ & .165 & 2.115 & .037 & $\begin{array}{l}\text { Need for } \\
\text { Achievement }\end{array}$ & .263 & 3.652 & .000 \\
\hline \multirow{2}{*}{\multicolumn{4}{|c|}{$\begin{array}{l}\text { Dependent variable: Entrepreneurial attitude } \\
\text { R Square: } .517 \\
\text { Adjust R Square: } .509 \\
\text { t table: } 1.659\end{array}$}} & $\begin{array}{l}\text { Entrepreneurial } \\
\text { Attitude }\end{array}$ & .431 & 5.147 & .000 \\
\hline & & & & \multicolumn{4}{|c|}{$\begin{array}{l}\text { Dependent variable: Entrepreneurial intention } \\
\text { R Square: } .607 \\
\text { Adjust R Square: } .597 \\
\text { t table: } 1.659 \\
\end{array}$} \\
\hline
\end{tabular}
tention $(\mathrm{Y})$ is described as follows:

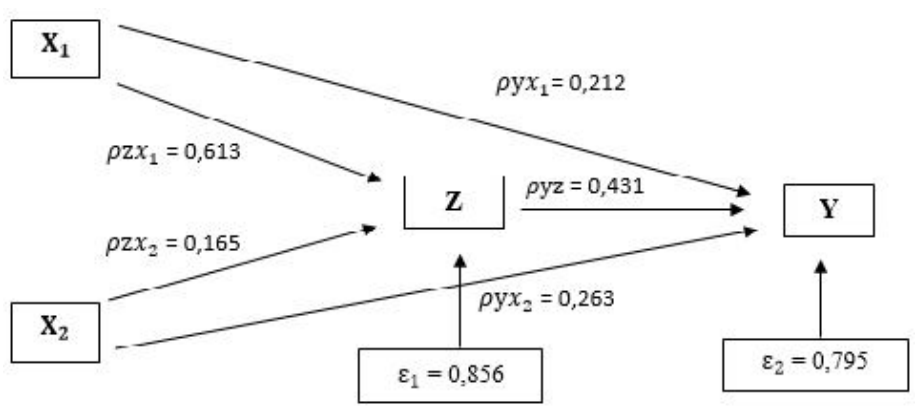

The influence of adversity quotient (X1) and need for achievement (X2) through entre-

Table 1 Model Linear Regression Summary I and II 
Dina Fitriya Maharani, Aniek Indrawati, \& Thusy Tiara Saraswati / The Influence of Adversity Quotient, Need for Achievement, and Entrepreneurial Attitude on Entrepreneurial Intention / JEE, Vol. 9, No. 1, March 2020, pp 9-16

preneurial attitude $(Z)$ on entrepreneurial intention $(\mathrm{Y})$ tested with multiple tests has been calculated. The results are shown in Table 2.

Table 2 Sobel Test Results

\begin{tabular}{lll}
\hline Variable & $\mathbf{t}$ count & $\mathbf{t}$ table \\
\hline $\mathrm{X}_{1}$ through $\mathrm{Z}$ on $\mathrm{Y}$ & 4.276 & 1.659 \\
\hline $\mathrm{X}_{2}$ through $\mathrm{Z}$ on $\mathrm{Y}$ & 1.952 & 1.659 \\
\hline
\end{tabular}

\section{DISCUSSION}

Based on the linear regression output in the first equation (table 1), the significance value of the adversity quotient variable (X1) is 0.000 and the need for achievement variable (X2) is 0.037 , which means it is smaller than 0.05 ( $\mathrm{sig} \leq 0.05)$. The t-value of the adversity quotient variable (X1) is 7.855 and the $t$-value of the variable need for achievement (X2) is 2.115 , with a t-table value of 1,659 . This means that adversity quotient (X1) and need for achievement (X2) affect the entrepreneurial attitude (Z).

Based on the linear regression output in the second equation (table 2), it is known that the significance value of the variable adversity quotient (X1) is 0.017 , the need for achievement variable (X2) is 0.000 and the entrepreneurial attitude variable $(Z)$ is 0.000 , which means it is smaller than 0.05 (sig 0.05). The tcount value of the adversity quotient variable (X1) is 2.423 , the $t$-value of the variable need for achievement (X2) is 3.652 and the t-value of the entrepreneurial attitude variable $(Z)$ is 5.147 , with a t-table value of 1.659 . This means that adversity quotient (X1), need for achievement (X2) and entrepreneurial attitude (Z) affect entrepreneurial intention $(\mathrm{Y})$.

A person's tendency to do certain behaviors is called intention. Therefore, intention is a component that exists in individuals who refer to the desire to do certain behaviors. Fishbein and Ajzen (1975) mention that intention is a component in an individual that refers to the desire to do a certain behavior. The same thing was also expressed (Sukmana, 2008) who says that the intention describes the desire to do something. Another opinion (Handaru et al., 2013) who explains that intentions are things that are assumed to explain motivational factors and have a strong impact on behavior. In line with this opinion, (Vemmy, 2013) states that intention is a part of an individual's self which is motivated by one's motivation to act. In another study, (Winne \& Adwin, 2012) asserts that intention is the motivation of someone who consciously decides to exert effort to carry out a behavior.

Firmansyah et al. (2016) mention that adversity quotient in entrepreneurial attitudes is a picture of how far someone's performance in facing challenges and solving problems in developing their business. A misfortune in a person will encourage the individual to try to adapt to every difficulty and demand flexibility of attitude so that he can survive in unexpected situations in entrepreneurship (Chen, 2007). KRTP recipients of the Jalin Matra Program who have a high adversity quotient, surely, have the ability to face adversity and are able to create opportunities from difficulties encountered to get better results. It can help facilitate the continuity of business development so that he will more easily undergo the profession as an entrepreneur because he has the ability to turn obstacles into opportunities.

An individual who has the intelligence to face obstacles is predicted to undergo the profession as an entrepreneur more easily because he has the ability to turn obstacles into opportunities (Stoltz, 2007). Based on this descrip- 
Dina Fitriya Maharani, Aniek Indrawati, \& Thusy Tiara Saraswati / The Influence of Adversity Quotient, Need for Achievement, and Entrepreneurial Attitude on Entrepreneurial Intention / JEE, Vol. 9, No. 1, March 2020, pp 9-16

tion, the researcher can conclude that individuals who have the intelligence to face obstacles will have the ability to capture business opportunities in entrepreneurship because they have the ability to bear risks, are oriented towards opportunities/initiatives, have creativity, are independent and are able to mobilize resources. Therefore, it can be concluded that adversity quotient in individuals have a relationship with his interest in entrepreneurship.

Need for achievement is a desire to do something better, be responsible, and dare to take risks. From these desires, good entrepreneurial attitudes are needed such as always behaving creatively and innovatively, thinking about the impact of decisions taken and being able to provide solutions to problems that occur. Ryan et al. (2011) argues that someone with a high need for achievement has a desire for challenging tasks that require abilities and effort, and provides clear feedback about their performance. The idea that individuals have stable characteristics that influence them towards certain behaviors or actions is the basis of research on human motivation (Ryan et al., 2011). The attitude itself has several objects including certain people, places, things, events, activities, mental concepts, cognitive orientation, lifestyle, or even a combination of these categories (Robinson et al., 1991).

Attitude is the basis for the formation of intentions (Wijaya, 2009). Ajzen (2002) attitude refers to the extent to which a person has a favorable or unfavorable evaluation or assessment of the behavior in question this is concerned with the action to become an entrepreneur. Regarding entrepreneurship, (Wijaya, 2007) states that entrepreneurship attitude is a tendency to react affectively in responding to the risks that will happen or occur in business.
According to Theory of Planned Behavior (Ajzen, 2005), entrepreneurship attitude is one of the factors that shape a person's intentions and subsequently will directly influence his behavior. Therefore, an understanding of one's intention to entrepreneurship (entrepreneurial intention) can reflect the tendency of people to establish a business in real terms.

\section{REFERENCES}

Anonimous. (2016). Evaluasi Program Kebijakan Jalin matra dalam meningkatkan pendapatan keluarga rentan miskin di Provinsi Jawa Timur, Badan Penelitian dan Pengembangan Provinsi Jawa Timur, Surabaya.

Chen, C. N., Tzeng, L. C., Ou, W. M., \& Chang, K. T. (2007). The Relationship among Social Capital, Entrepreneurial Orientation, Organizational Resources, and Entrepreneurial Performance for New Ventures. Contemporary Management Research, 3(3).

European Comission. (2012). Effects and Impact of Entrepreneurship Programmes in Higher Education. Brussels: European Union.

Firmansyah, A. H., Djatmika, E. T., \& Hermawan, A. (2016). The Effect of Adversity Quotient and Entrepreneurial Self Efficacy on Entrepreneurial Intention through Entrepreneurial Attitude. Journal of Business and Management, 18(5), 45-5.

Fishbein, M. \& Ajzen, I. (1975). Belief, Attitude, Intention, and Behavior: An Introduction to Theory and Research. Reading, MA: Addison-Wesley.

Handaru, A. W., Waspodo, A., \& Carolina, C. (2013). Motivational Factors, Entrepreneurship, Gender, and Parental Back- 
Dina Fitriya Maharani, Aniek Indrawati, \& Thusy Tiara Saraswati / The Influence of Adversity Quotient, Need for Achievement, and Entrepreneurial Attitude on Entrepreneurial Intention / JEE, Vol. 9, No. 1, March 2020, pp 9-16

ground: Evidence from the Tailor's Guild at Sunan Giri Traditional Market, Jakarta, Indonesia. China-USA Business Review, 12 (6), 627-635.

Harniati. (2007). Tipologi Kemiskinan dan Kerentanan Berbasis Agroekosistem dan Implikasinya pada Kebijakan Pengurangan Kemiskinan. http://repository.ipb.ac.id/ handle/123456789/2 756.

Katz, J. dan W, Gartner. (1988). "Properties of Emerging Organizations". Academy of Management Review, 13(3), 429-441.

Kearney, C., Hisrich, R., \& Roche, F. (2008). A Conceptual Model of Public Sector Corporate Entrepreneurship. International Entrepreneurship and Management Journal, 4(3), 295-313.

Mopangga, H. (2014). Faktor Determinan Minat Wirausaha Mahasiswa Fakultas Ekonomi dan Bisnis Universitas Negeri Gorontalo. Trikonomika, 13(1), 78-90.

Nurmawati, Y. (2017). Efektivitas Program Jalin Matra Penanggulangan Kerentanan Kemiskinan di Desa Ngroto Kecamatan Pujon Kabupaten Malang.

Robinson, P. B., D. V. Stimpson, J. C. Huefner, and H. K. Hunt. (1991). An Attitude Approach to the Prediction of Entrepreneurship. Entrepreneurship Theory and Practice, 15(4), 13-30.

Ryan, J. C., Tipu, S. A., \& Zeffane, R. M. (2011). Need for Achievement and Entrepreneurial Potential: A Study of Young Adults in the UAE. Education, Business and Society: Contemporary Middle Eastern Issues, 4(3), 153-166.
Sénchez, V. B., \& Sahuquillo, C. A. (2012). Entrepreneurial Behavior: Impact of Motivation Factors on Decision to Create a New Venture. Investigations Europeas a'e Direccio'n y Economia de la Empresa, 18, 132-138.

Winne, P. H., \& Hadwin, A. F. (2012). The Weave of Motivation and Self-Regulated Learning. In Motivation and Self-Regulated Learning (pp. 309-326). Routledge.

Stoltz. P. G. (1997). Adversity Quotient-Turning Obstacles into Opportunities. United States: John Wiley \& Sons, Inc.

Sukmana, U. D. (2008). Peran Pendidikan Kewirausahaan dalam Menumbuhkan Motivasi (Studi tentang Pengaruh Pendidikan Kewirausahaan terhadap Motivasi Wirausaha Mahasiswa Universitas Kuningan). Equilibrium, 4(8), 1-23.

Vemmy, S. C. (2013). Faktor-Faktor yang Mempengaruhi Intensi Berwirausaha Siswa SMK di Yogyakarta. Jurnal Pendidikan Vokasi, 2(1), 117-125.

Wijaya, T. (2007). Hubungan Adversity Intelligence dengan Intensi Berwirausaha Studi Empiris pada Siswa SMKN 7 Yogyakarta. Jurnal Manajemen dan Kewirausahaan, 9(2), 107-116.

Wijaya, T. (2009). Kajian Model Empiris Perilaku Berwirausaha UKM DIY dan Jawa Tengah. Jurnal Manajemen dan Kewirausahaan, 10(2), 93-104.

Zaki, A., Fadzely, M., \& Ahmed, E. M. (2006). Study of Motivation in Business StartUps among Malay Entrepreneurs. International Business \& Economics Research Journal, 5(2), 103-112. 
Dina Fitriya Maharani, Aniek Indrawati, \& Thusy Tiara Saraswati / The Influence of Adversity Quotient, Need for Achievement, and Entrepreneurial Attitude on Entrepreneurial Intention / JEE, Vol. 9, No. 1, March 2020, pp 9-16 